\title{
The Open Society and "British Soft Power" in Central/Eastern Europe at the End of Cold War
}

\author{
Carola CERAMI
}

In his book "Erasmians" Ralf Dahrendorf explored "the wellsprings of the liberal spirit". ${ }^{1}$ He focused on a generation of "public intellectuals" 2 born in the first decade of the $20^{\text {th }}$ Century, who grew up under the shadow of increasing Soviet power as well as the rise of Fascism and then of Nazism. In particular, he refers to three intellectuals: Isaiah Berlin, Raymond Aron and Karl Popper, calling them "Erasmians", because like Erasmus from Rotterdam, they were steadfast, under the most adverse conditions, in their adherence to core liberal ideas. Dahrendorf conferred the label of "Erasmian nation" on Great Britain, a country he considered to be immune from the temptations of authoritarianism and totalitarianism.

The "Erasmian" intellectuals cited by Dahrendorf played a leading role in the defence of the liberal spirit throughout the $20^{\text {th }}$ Century. This article will attempt to highlight the equally important role played by British intellectuals of Central European origins from a successive generation who were inspired by the Erasmians and committed to the liberalization of the Eastern European countries the 1980s and 1990s. Their engagement in this process is represented by the concrete application of their ideas on freedom and the Open Society.

As pointed out in the introduction, "in the second half of the 1980s Britain deployed a wider, more active and more effective Ostpolitik than at any time since the onset of the Cold War". ${ }^{3}$ This process was advantaged by the new climate of détente and had an extraordinary influence on East-West relations before the end of the Cold War. The "new détente" was also, as Mary Kaldor noted,

"a strategy of dialogue, an attempt to change society through the actions of citizens rather than governments, to change ideas and to develop new institutions; in short to create a new political culture". ${ }^{4}$

This article will analyse one specific aspect of cultural exchanges at the end of the Cold War in Europe, namely the influence of those intellectuals based in Great Britain who promoted a "strategy of dialogue" between intelligentsias on both sides of the

1. R. DAHRENDORF, Erasmiani. Gli intellettuali alla prova del totalitarismo, Editori Laterza, RomaBari, 2007 (title of the original edition: Versuchungen der Unfreiheit. Die Intellektuellen in Zeiten der Prüfung, Verlag C.H. Beck, München, 2006).

2. Dahrendorf's definition of "public intellectual" was the following: "We are not dealing with intellectuals in general, but with those whom I call public intellectuals [...]. The concept of public intellectual has a stronger meaning. These are people who believe it is an imperative of their profession to participate in the leading public debates of their time, indeed, to determine their contents and direct their development". See R. DAHRENDORF, Erasmiani ..., op.cit., p.14.

3. See the introduction to this issue.

4. M. KALDOR, G. HOLDEN, R. FALK, The New Détente. Rethinking East-West Relations, Verso, United Nation University, New York, 1989, p.15. 
Iron Curtain. The principal objective will be to highlight the most significant cultural initiatives originating in Britain that were directed towards Central and Eastern Europe from the end of the 1980s to the beginning of the 1990s under the banner of the Open Society. ${ }^{5}$ The issue of Open Society will therefore represent the central theme of this article. However the main focus will not be on the philosophical or sociological debate on this idea but rather on the dimension of active engagement which it inspired. The kind of "British soft power" which is described in the following pages is therefore the result of the fusion of two processes: the intellectual attraction exercised by a rich debate on liberalism in Britain and the capacity of thinkers such as Ralf Dahrendorf and Ernest Gellner to engage in the active pursuit of the Open Society in the other half of Europe.

This approach raises three fundamental questions:

- How significant was the exchange of ideas between East and West at the end of the Cold War and in particular what was the role played by the intellectuals discussed here?;

- How meaningful and innovative was the expression "A Common Market of the Mind in Europe" used by Dahrendorf?;

- Did liberal ideas emanating from Great Britain exercise a true "power of intellectual attraction" on Eastern Europe, influencing the debate on inter-European relations in the 1980s and 1990s?

The article may not provide definite answers to these questions but by raising them and focusing on their meaning, it will shed light on the active engagement in Central Eastern Europe of a small group of intellectuals of central European origins, operating in Britain. Their main goal in the years just before and after the end of the Cold War was to put to test their theoretical models based on the Open Society on the other side of the Iron Curtain. In order to sustain this approach the article will examine the role played by selected foundations and publishers that disseminated the ideas of the Open Society within Central-Eastern Europe. These include the "Central and East European Publishing Project" (CEEPP), whose establishment was strongly backed by Dahrendorf and Timothy Garton Ash and operated from 1986 to 1994. In addition, there was the foundation of the "Centre for the Study of Nationalism" at the Central European University of Prague (CEU). This Institution was Gellner's main opportunity of active engagement in Eastern Central Europe. He directed it between 1994 and 1995 and played, together with George Soros and Al Stepan, a leading role in its development.

These initiatives were mainly inspired by two people: Dahrendorf and Gellner. These two very prominent scholars, both born in the 1920s in Central Europe, shared a common experience of the horrors of totalitarianism and of adopting Great Britain as their elective homeland. Their backgrounds allowed them to maintain close links with Central and Eastern European countries and enhanced their efforts to mediate and encourage dialogue between Eastern and Western Europe. Personal experiences

5. The term open society was first introduced by Henri Bergson in 1932, when he published his Two Sources of Religion and Morality. 
also heightened their sensitivity to questions of freedom and to the struggle against totalitarianism. However, it was Great Britain that fostered their intellectual development and enabled them to create an academic and cultural network for the elaboration of ideas and projects.

Britain, the "Erasmian Nation" provided a unique environment for debating ideas and spreading them. Dahrendorf and Gellner became British but remained "European". Their origins and their links with the European cultural world heightened their sensitivity to issues associated with the concept of Open Society and inspired them to dedicate most of their intellectual efforts to elaborating the theory and practice of freedom. Starting from Karl Popper's observations, Dahrendorf and Gellner developed, expanded and deepened the concept of 'open' as opposed to 'closed' societies. They were both profoundly influenced by Popper's insistence on establishing and testing knowledge and his studies on the Open Society, which they both developed, in different directions, beyond Popper himself.

It should be pointed out here that these two intellectuals were not particularly close personally, did not work together as a team, nor did they share political allegiances. However, for both, the reading of Popper's work The Open Society and Its Enemies represented a milestone in their intellectual development. Karl Popper, the "Erasmian", completed his manuscript in 1943 during the Second World War. ${ }^{6}$ At the time he considered it his "war work", that is his contribution to the war effort, given his liminal status as an enemy alien domiciled in the Dominion of New Zealand. The war was being fought against Fascist power, but he regarded Communism as a more insidious menace waiting in the wings should the current enemy be defeated. ${ }^{7}$ This book attracted immediate attention after its publication in 1945, but its real triumph came later. In the enthusiasm generated by the 1989 revolution, The Open Society and Its Enemies became essential reading throughout the post-communist world. After the fall of the USSR's Eastern European empire in 1989, there arose a great need to build free and democratic institutions, and to reintroduce notions of freedom of thought, critical thinking, and intellectual inquiry in the former Soviet bloc countries. ${ }^{8}$ Popper, from his chair in Logic and the Scientific Method at the London School of Economics that he held from 1949 onwards, became the point of reference for a whole generation of scholars inspired by his view of the Open Society.

Dahrendorf and Gellner's unique contribution lay in their ability to combine abstract political theory with an approach to the concrete problems of Eastern and Central Europe. Each, however, acted independently in creating networks that not only

6. K. POPPER, The Open Society and Its Enemies, vol.1-2, Routledge Classics (new edition), London, 2002. Karl Popper was born into a Jewish family in Vienna in 1902. In 1937 he was forced to emigrate to New Zealand. Popper's manuscript on the open society (written in 1945) came to the attention of Friedrich von Hayek, then a Professor at the London School of Economics. In 1946 von Hayek freed Popper from his New Zealand exile by inviting him to the LSE. Great Britain thus became Popper's new homeland and the base for the dissemination of his ideas.

7. I. JARVIE, S. PRALONG, Popper's Open Society After 50 Years. The Continuing Relevance of Karl Popper, Routledge, London, 2003, p.XI.

8. Ibid., p.8. 
involved other scholars but also brought in journalists, practitioners and diplomats. Research at the Gellner Collection held at the archives of the London School of Economics, particularly his correspondence in the early 1990s, has made it possible to reconstruct the intellectual and academic network that lay behind the establishment of the Centre for the Study of Nationalism at the Central European University of Prague. Indeed, both Dahrendorf and Gellner felt very strongly from the second half of the 1980s and the early 1990s, that it was necessary to step beyond purely intellectual debates in order to take advantage of the changes occurring in Europe. They directed their initiatives towards Central and Eastern Europe, starting from the dissemination of selected publications and books in translations and creating a "secret channel" funding or exporting intellectual work from Eastern Europe. The second objective was to invest in education with the objective of revitalizing the civil societies that lay East of the Iron Curtain. ${ }^{9}$

\title{
"A Common Market of the Mind in Europe": Ralf Dahrendorf and the "Oxford Project"
}

\section{In 1990 Ralf Dahrendorf wrote in Reflections on the Revolution in Europe:}

\begin{abstract}
"The countries of East Central Europe have not shed their Communist system in order to embrace the capitalist system (whatever that is); they have shed a closed system in order to create an Open Society, the Open Society to be exact, for a while there can be many systems, there is only one Open Society. [...] The road to freedom is not a road from one system to another, but one that leads into the open space of infinite possible futures, some of which compete with each other. Their competition makes history". ${ }^{10}$
\end{abstract}

Dahrendorf's concept of the Open Society contains two strongly interrelated factors: change and complexity. If the greatest danger to the Open Society derives from dogma, or from the monopoly of control by a group, an ideology, or a system, then the first step must be opening to change, to evolution. At the same time an Open Society is intrinsically complex. To fulfil the exciting perspective of open horizons, one must deal with conflict, difficulties, uncertainties, in other words to develop complexity. Open societies are those that allow trial and error.

As Dahrendorf himself noted, the term Open Society is more eye-catching than it is precise, and the differences between open societies and closed societies are even more significant than Popper himself thought. Dahrendorf believed that the open

9. This article is the result of my work as a researcher within the framework of the research project "A Destiny and a European identity beyond the boundaries of the Cold War? The Ostpolitik of Great Britain and the new battlefield of ideas in Eastern Europe (Hungary, Poland and Czechoslovakia) 1984-1992", lead by Ilaria Poggiolini at the University of Pavia. I am indebted to Professor Poggiolini for her invaluable leads to the analysis of the theme of this article and to the relevant sources.

10. R. DAHRENDORF, Reflections on the Revolution in Europe: In a Letter Intended to Have Been Sent to a Gentleman in Warsaw, Times Books, New York, 1990, pp.40-41. 
society was principally a guiding principle that also needed to be integrated with other ideas. The most immediate task according to Dahrendorf was "to fill the structures of the open society with the lifeblood of civil society". ${ }^{11}$ Open societies multiply options, closed societies reduce them. An open society benefits from a variety of options: different types of media as well as plural political parties, opportunities for access and a full range of human rights. ${ }^{12}$

For Dahrendorf, who was born in Germany and had experienced imprisonment as a very young dissident in the Nazi era, though for a shorter period than his father, the years 1945 and 1989 represented two extraordinary and inimitable moments of freedom. Both the end of World War II and the end of the Cold War marked the defeat of those enemies of the Open Society which he had seen in action. In Dahrendorf's view, these two unique events should have paved the way to a rainbow of new possibilities, not simply to a single model of democracy and market economy. ${ }^{13}$

Moments and places were equally important in forming and strengthening Dahrendorf's intellectual and political convictions. His "discovery of the West" coincided with his arrival in and discovery of Britain in the 1950s, where he completed a second doctorate at the London School of Economics (LSE). ${ }^{14}$ Britain and her institutions remained central to Dahrendorf's life and he distinguished himself in the British academic and political scenario as Director of the LSE between 1974 and 1984, as a life peer from 1993 onwards and as the Warden of St. Antony's College, Oxford, between 1987 and 1997. ${ }^{15} \mathrm{He}$ would recall with great enthusiasm the end of the 1980s and the early 1990s at St. Antony's College at Oxford. Here the study of Communist Europe had a long tradition and among the fellows, ${ }^{16}$ Timothy Garton Ash shared Dahrendorf's commitment to promote change in Eastern Central Europe. The result was the opening of a real channel of communication of ideas and people. As Dahrendorf himself recalled:

11. R. DAHRENDORF, After 1989: Morals, Revolution and Civil Society, MacMillan Press, London, p.23.

12. According to Dahrendorf an Open Society is a society that promotes natural change, it is a mobile society in the wider sense of the word, embracing social (increase and decrease), geographic (geographic movements and migratory phenomena) and economic factors (mobility of the factors of production). It is a society endowed with a healthy and robust civil society, capable of expressing itself through a "creative chaos" variously made up of associations, religious institutions, artistic forms, educational institutions and sporting events, that includes entertainment as well as social, environmental and volunteer activities. See R. DAHRENDORF, La società riaperta. Dal crollo del muro alla guerra in Iraq, Laterza, Roma -Bari, 2005, pp.22-35 (title of the original edition: Der Wiederbeginn der Geschichte. Vom Fall der Mauer zum Krieg im Irak, Verlag C.H. Beck, München, 2004).

13. Ibid., p.199.

14. R. DAHRENDORF, Why Europe matters. A personal view, Centre for European Reform, London, 2002.

15. R. DAHRENDORF, Oltre le frontiere. Frammenti di una vita, Laterza, Roma/Bari, 2004 (title of the original edition: Über Grenzen. Lebenserinnerungen, Verlag C.H. Beck, München, 2002).

16. A. BROWN, Margaret Thatcher and Perceptions of Change in the Soviet Union, in this issue. 
"The close friendships between Eastern reformers and their active supporters in the West led to an exchange of ideas capable of changing life. [...] It was a pleasure to witness with open eyes this era when freedom erupted". ${ }^{17}$

The year 1989 was in the first place for Dahrendorf "a great moment of freedom":

"The revolution of 1989 changed Europe. It changed the world. For my life and my understanding of the world, it indicated a fundamental turning point as important as 1789 . When I published a volume of collected essays titled After 1989, I meant with that title to highlight how in that fateful year many social political and economic issues took on a new colour. It was a change for the better, because it was change towards open societies". ${ }^{18}$

Dahrendorf believed that an important impulse towards the 1989 revolution came from "glasnost", in other words, from the realization that apparently even a small dose of freedom of opinion could make the foundations of the regime tremble. With "glasnost" the moment of the intellectuals had come. The year 1989 brought in radical change, and a unique opportunity for those public intellectuals who had cultivated values inspired to Erasmian principles. Indeed 1989 and the end of totalitarianism in Europe highlighted once again the great dilemma of the vita activa of public intellectuals. ${ }^{19}$ Dahrendorf's reflections on this theme were principally directed towards Eastern European intellectuals, who at that time were actively challenged by the transition from communism to post-communism. However, Dahrendorf also felt a strong need to urgently engage with Central and Eastern Europe. He wrote at the time:

"Intellectuals have a public responsibility. Where they remain silent, societies have lost their future....It is the responsibility of intellectuals to speak up and thereby address those involved in the trials and tribulations of active life". ${ }^{20}$

Dahrendorf's active commitment towards Central and Eastern Europe in those years is exemplified by two initiatives:

"There were two sectors where I was personally involved in helping to promote civil societies in the post-communist world. One was the "Central and East European Publishing Project", on which a very well documented book has been published under the title: Publishing for Freedom - Freedom for Publishing. This small foundation had the objective of supporting the translation and publication of books and journals. My other contribution was through the Hannah Arendt Prize, awarded for exemplary reforms in higher education and research within Central and Eastern Europe. Both these projects helped bring publishing and higher education in the post-communist countries of Europe into a wider European context. If today there remains a need to support publishing and higher education, it can and must be pan-European or more simply, European". 21

The "Central and East European Publishing Project" (CEEPP) had Dahrendorf as creator and protagonist together with Timothy Garton Ash. The CEEPP was a small

17. R. DAHRENDORF, La società riaperta ..., op.cit., p.5.

18. R. DAHRENDORF, 1989. Riflessioni sulla rivoluzione in Europa, Laterza, Roma/Bari, 1999, p. 150.

19. R. DAHRENDORF, Erasmiani ..., op.cit., pp.204-205.

20. R. DAHRENDORF, After 1989 ..., op.cit., p.122.

21. R. DAHRENDORF, 1989. Riflessioni ..., op.cit., p.151. 
foundation (commonly called "the Oxford project"), whose head office was located in Oxford, and whose primary objective was to encourage the free exchange of ideas in the countries of Central and Eastern Europe, to create a "free flow of culture between East and West Europe" and above all, to launch, using an expression coined by Dahrendorf himself: "A Common Market of the Mind in Europe" between East and West. The project was inspired by the idea of creating a "marketplace", in the old liberal meaning of the word, a place where it was possible to exchange ideas, and where such an exchange could generate new ideas. One can argue that this was a small but concrete attempt to spread Western ideas in the East and vice versa, and to enhance the exchange of ideas among the Eastern European countries. The project began in 1986 and was prompted by the concept that the geopolitical division of Europe - the Iron Curtain - had interrupted not only the normal beneficial flow of people between East and West, but also the exchange of ideas and culture. For this reason the project centred on two main initiatives: "continued publication" (in Polish, Hungarian, Czech, etc.) and "improved translation" (from, to and between these languages), it focused especially on three countries in central Eastern Europe: Poland, Hungary and Czechoslovakia. ${ }^{22}$

The experience of the Oxford Project, as observed by Garton Ash, was not a "short history of a small organization", but rather "a small contribution - a footnote, if you will - to that great transformation". ${ }^{23}$ The question is, as very clearly pointed out by Dahrendorf himself in discussing the role of publishing and of foundations in reviving civil society:

"In an open world, civil society is simply the ordinary medium of life, the untidy universe of organizations and institutions, of small businesses and universities and local communities and associations of many kinds in which we spend our days [...]. Publishing is a central part of civil society. Newspapers and journals and books are perhaps the most visible index of whether there is an autonomous sphere of associations or whether government determines all. Publishing is at the heart of civil society. [...] One other aspect of civil society is foundations. Foundations as one of the keys to the reality of civil society". ${ }^{24}$

The Oxford Project ended in 1994. After 1989 it aimed at supporting the transition to post communist societies.

In those years it was Garton Ash, with his contribution to the "Central and East European Publishing project", who played an important role in the circulation of ideas between these two parts of Europe. He was an active participant in those events and he wrote about them for newspapers and journals. His articles and essays from Berlin,

22. This project was funded by a number of foundations (these included: the Ford Foundation, the European Cultural Foundation, the Rockefeller Foundation and George Soros' The Open Society Foundation). Besides Garton-Ash and Dahrendorf, the founding members included: François Furet, Raymond Georis, Jane Kramer, Laurens van Krevelen and Pet Wastberg.

23. T. GARTON ASH (with contributions from R. DAHRENDORF, R. DAVY, E. WINTER), Freedom for Publishing, Publishing for Freedom. The Central and East European Publishing Project, Central European University Press, Budapest, 1995.

24. Ibid., p.11. 
Warsaw, and Budapest are important sources for a reconstruction of the social, cultural and historical political climate of that era. ${ }^{25}$ From 1990 onwards, Dahrendorf would enthusiastically single out Garton Ash, among the fellows from St. Antony's College in Oxford, for his commitment and active contribution to the events of 1989. ${ }^{26}$ In his book on the events of 1989, We the People, Garton Ash used the term "revolutions of intellectuals" in referring to the role played by certain Eastern European intellectuals such as Vaclav Havel, Adam Michnik, George Konrad, Bronislaw Geremek and others. ${ }^{27} \mathrm{He}$ asserted that these intellectuals played a decisive role both in the events of 1989 and in the following phase, during the complex process of democratic transition.

\section{Recently Garton Ash has argued that}

"people like me and others managed to tell a different story about what was happening in Eastern Central Europe in the mid 1980s and I think that had some impact on policy makers even possibly on MT but certainly on the Foreign Office [...], but it was crucial to think of this story as the emancipation of a part of Europe who felt it belonged to the West". ${ }^{28}$

The idea of a "return to Europe" and of belonging to "the West" had a strong impact among the intellectuals of Central and Eastern Europe, but just as important was the "power of attraction" that the West exercised on the East. In the light of this double exchange, the part played by British intellectuals, on whose role this article has focused, does not appear to be secondary. Although they may not have succeeded in creating a "pan-European East-West network of intellectuals", they nevertheless made an important contribution to the spread of freedom of expression in Central Eastern Europe, as well as to a courageous "exchange of ideas between East and West" during a crucial phase of contemporary history.

25. T. GARTON ASH, The Polish Revolution: Solidarity, Penguin Books, London, 1999 (written in 1983); T. GARTON ASH, We The People, Penguin Books, London, 1999 (written in 1990); T. GARTON ASH, The Uses of Adversity, Penguin Books Ltd, London, 1999 (written in 1989); T. GARTON ASH, History of the Present: Essays, Sketches and Despatches from Europe in the 1990, Penguin Books, London, 2000. See also Garton Ash's Internet site:www.timothygartonash.com.

26. T. GARTON ASH, We The People, op.cit.; see also R. DAHRENDORF, Reflections on the Revolution ..., op.cit.

27. T. GARTON ASH, We The People, op.cit.

28. See Garton Ash in conversation with Ilaria Poggiolini, 22 October 2009, St. Antony's College, Oxford. 


\section{Behind the Creation of the Central European University: Ernest Gellner and George Soros}

Ernest Gellner was forced into exile by Nazism and emigrated to Great Britain: his adopted homeland. ${ }^{29}$ In a long interview by John Davis published by Current Anthropology in 1991, Gellner told the story of his life, beginning with his childhood in Prague, fleeing with his family to Great Britain at the age of 13 and later studying at the LSE and Cambridge University. ${ }^{30}$ Gellner was a Professor of Philosophy, Logic and Scientific Method at the LSE between 1962 and 1984, under Dahrendorf's directorship. Intellectually, both subscribed to and embraced the empirical method and liberal ideas, and were determined to further pursue Karl Popper's reflections on the open society, a notion that both thinkers developed beyond Popper, albeit reaching different conclusions.

From the mid 1980s to the mid 1990s, Gellner became increasingly concerned with Eastern Europe and particularly with the impact of Marxism on civil society. Between the years 1984 and 1994 he held the position of a Professor for Social Anthropology at the University of Cambridge. In 1988/89 he had the opportunity to spend a year in Moscow. This was the time and place when Gellner was able to take a closer look at the course of events taking place in Central and Eastern Europe. ${ }^{31}$ His deep involvement in this extraordinary transformation alongside his very eclectic intellectual interests make him a significant test case not only in terms of the dissemination of liberal ideas in Eastern Europe, but also for his central role in the intellectual debate in Britain on the future of Central Eastern Europe from the end of the 1980 s to the mid 1990s.

A radical shift towards active engagement in Central Eastern Europe came for Gellner in 1994 when he became the Director of the Centre for the Study of Nationalism at the Central European University (CEU) in Prague. ${ }^{32}$ George Soros was among the prominent founders and sponsors of the CEU and first Chairman of the CEU Board. ${ }^{33}$ The overall idea of the CEU was to establish a network-university whose priorities were to foster research on the transition of post-Communist societies to market economy and political liberalisation, to encourage an intense exchange of scholars and students between Eastern and Western Europe, and finally to contribute to the long term goal of creating the Open Society in Central and Eastern Europe. The CEU became a significant think-tank in the very heart of Central Eastern Europe. On

29. Gellner began his academic career in 1947 at the University of Edinburgh moving to the London School of Economics (LSE) in 1949.

30. J. DAVIS, An interview with Ernest Gellner, in: Current Anthropology, 1(1991), pp.63-72. Gellner was born in Paris in 1925 and spent his childhood in Prague. The rise of Nazism forced his family to move to Great Britain in 1939.

31. He relates this experience in his interview with N. KEDDIE, A Year in the Soviet Union (recorded 7 July 1990), in: Contention, 2(Winter 1992), pp.107-120.

32. The CEU was founded in 1991 with the express purpose of encouraging, through education, the democratic transition process in Central and Eastern Europe and Central Asia.

33. The first Rector was Alfred Stepan. 
July 4th 1993, before accepting his appointment as Director of the Centre for the Study of Nationalism, Gellner wrote to Soros outlining his concerns regarding the position in his characteristically vigorous prose:

"The task in hand is not an easy one. One is supposed to say something of importance about one of the most intractable and difficult and important problems facing post-Communist Europe. There are now 28 or 29 post-Communist countries (according to whether one counts East Germany), presenting a considerable diversity of conditions. I can't guarantee success in generating ideas about all this, but I'm eager to have a determined try. Quite apart from the inherent intellectual difficulty of the task, working in Prague, Moscow, and presumably the crucial areas of the ex-USSR and ex-communist empire, will really make it a hell of a job. I am willing to try, but only if I have proper support [...]". 34

Gellner ultimately accepted the position and entered the fray, strongly motivated by the need to actively engage with the transformation of Central Eastern Europe. The difficulties of the transition to democracy in the area demanded active participation and events taking place in his native city of Prague were also a very strong incentive to take action. In particular, Gellner felt that theoretical concerns should be able to underpin a practical commitment to resolving the real problems of Central and Eastern Europe. On October 30th 1995, in a letter to George Soros, he wrote:

"We are studying Nationalism because it constitutes one of the major threats to the emergence of stable, liberal and prosperous societies in Eastern Europe. But another and equally important threat is the moral and intellectual vacuum left behind by the collapse of communism (which after all wasn't displaced by a rival, but simply collapsed, leaving a vacuum). The enquiry into philosophical and political issues at the Centre would really be guided by this consideration". ${ }^{35}$

Indeed, the Gellner Collection allows researchers to partially reconstruct the dynamics of the exchange between Gellner, Soros and Stepan in the early 1990s. ${ }^{36}$ This correspondence mainly concerned the activities and development of the Central European University, but it also reveals the important role played by this group of scholars and thinkers who shared a common commitment to the struggle against totalitarianism and the opening up of closed societies.

In 1994 Gellner published Conditions of Liberty: Civil Society and Its Rivals, a title inspired by Popper's The Open Society and Its Enemies. In this work, Gellner elaborated his original thoughts on the uniqueness of Western civil society and the relationship between Communism and Liberalism, state and society, democracy and totalitarianism. ${ }^{37}$ As already pointed out, Popper was at the origin of Gellner's involvement with the concept of Open Society and his belief in the importance of fos-

34. Gellner's correspondence for those years can be consulted in the Gellner Collection, which is held in the LSE Archive in London. LSE ARCHIVES, Gellner Collection, Box 54, Gellner to Soros, 04.07.1993.

35. Ibid., Box M 1913 File 6, Gellner to Soros, 30.10.1995.

36. Ibid., Box M 1913 File 4, 7, 31; Box 54.

37. E. GELLNER, Condition of Liberty: Civil Society and Its Rivals, Hamish Hamilton Ltd, London, 1994. 
tering civil society. ${ }^{38}$ Popper visited the Central European University on May 26th 1994. In Prague he received an honorary degree at Charles University and chaired a seminar at the Central European University. Popper and Gellner were one generation apart, but they had Central European origins in common, as well as the experience of exile in the 1930s. Now they found themselves in the same city and on the same platform, giving voice to plans to bring lasting freedom to the region. ${ }^{39}$ Popper died only a few months later on September 17th 1994.

In the year following Popper's death, Gellner launched the idea of a conference to be held at the CEU to celebrate the fiftieth anniversary of the publication of The Open Society and Its Enemies. The conference was held between the $9^{\text {th }}$ and $10^{\text {th }}$ November in 1995. This conference is significant because its principal objective was, as Gellner wrote to Stepan on April 25th: "to combine abstract political theory with the concrete problems of Eastern and Central Europe". ${ }^{40}$ In a letter to Soros and other guests, dated May 18th 1995, Gellner explained the meaning and the importance of this event:

"The month of November 1995 marks the fiftieth anniversary of the publication of The Open Society and its Enemies. This is obviously one of the outstanding formulations of Liberalism of the century. It was written against the background of the Second World War, and its author himself, in my hearing, once described it as a "fighting book": he evidently considered it his contribution to the war effort. Since then, the book has provided inspiration for people locked in a different conflict with a different totalitarianism".

The letter continued, emphasising a key aspect:

"Its ideas constitute a kind of intellectual foundation for the Central European University and the institutions connected with it, as indeed is manifest from the names of some of them. The CEU is planning to hold a conference to mark this fiftieth anniversary [...]. The problems for discussion will include: 1 . The distinctive problems of building stable, free and prosperous societies on the ruins of Marxist absolutism. To what extent has Communism bequeathed a moral and institutional vacuum? Does the aspiration to build an Open or Civil Society face distinctive problems in the post-Communist world? 2. In what ways can or need post-Communist societies come to terms with the period of Marxist domination? What does it show concerning the regrettable potential of societies for totalitarism? 3. The central theme of Popper's work was the linkage of science and Liberalism. How have these ideas stood up? 4. Do we need, and can we have a general sociology of the preconditions of Open or Civil Societies"? ${ }^{41}$

Gellner's central objective in organising the conference was to highlight the role played by Popper's book, The Open Society, in inspiring initiatives, projects and the very idea of the Central European University in the name of the Open Society. Gellner also intended to launch a debate on how an Open Society can be built, and on the

38. M. IGNATIEFF, On Civil Society: Why Eastern Europe's Revolutions Could Succeed, in: Foreign Affairs, March/April 1995.

39. I. JARVIE, S. PRALONG, op.cit., p.9.

40. LSE ARCHIVES, Gellner Collection, Box M 1913, File 4, Gellner to Al Stepan, 25.04.1995.

41. Ibid., Box M 1913, File 26, Gellner to Soros, 18.05.1995. 
complexity of the transition in post-Communist Europe. Suddenly Gellner died only a few days before the conference he had so carefully planned, on November $5^{\text {th }}$ $1995 .{ }^{42}$ His work as Director of the Centre for the Study of Nationalism, and the network of intellectuals involved with the activities of the CEU, are but one further example of initiative launched in the name of the Open Society by public intellectuals with strong links with the London School of Economics.

George Soros, the Chairman of the CEU Board, was also linked to the LSE. Of Hungarian origin and of the same generation as Gellner and Dahrendorf, Soros emigrated to Great Britain in 1947. He studied at the LSE with Popper. His reading of how Popper's ideas could inspire action went in the direction of encouraging critical thinking in education as a precondition for the creation of an active and lively, civil society. Soros himself described the importance of Popper's influence on his view of Open Society:

"As a student after World War II, I adopted Popper's concept of Open Society with alacrity. As a Hungarian Jew who first escaped extermination by the Nazis by adopting a false identity and then escaped Communism by emigrating, I learned at an early age how important it is what kind of social organization prevails. Popper's dichotomy between open and closed societies seemed to me profoundly important. Not only did it illuminate the fundamental flaw in totalitarian ideologies but also threw light on some basic philosophical issues. It is his philosophy that guided me in establishing my network of Open Society Foundations". ${ }^{43}$

Indeed the Open Society Foundation was by statute directed at opening closed societies, strengthening open societies and promoting critical thinking. The foundation focused its energies on Central and Eastern Europe, creating in 1984 a foundation in Hungary and a second one in 1987 in Poland. As the Soviet empire disintegrated, the Foundation continued to set up institutions inspired by the idea of the open society elsewhere and by 1991 its network covered over twenty countries. Looking back, Soros commented:

"Those years were revolutionary not only for the countries of the ex-Soviet empire, but also for me and my network of foundations [...]. I felt I had to dedicate all my energies to the establishment of foundations. The Central European University's role was to act as a think-tank for the foundations [...]. I wanted my foundations to become prototypes for the 'open society', but then I realized that this ambition would be a constructive mistake. An open society must be able to support itself, while the survival of my foundations depended on my funding them. In reality they acted like a deus ex machina; but a deus ex machina is exactly what was needed to change the course of history. [...] It was such a vast undertaking that without external help it would have been impossible to ensure the transition

42. Revised and reconsidered texts prepared in the light of the conference's discussions were published in I. JARVIE, S. PRALONG, op.cit.

43. G. SOROS, Open Society. Reforming Global Capitalism, Little Brown, London, 2000, pp.xxi-xxii. 
from a closed to an open society. It was this realisation that led me to dedicate all my energies and my resources to providing such assistance". ${ }^{44}$

Soros' correspondence with Gellner over the years of the creation and establishment of the CEU is ongoing. This correspondence confirms the role played by Soros in sharing an innovative project based on the understanding of the urgent need to invest in education in Central and Eastern Europe. ${ }^{45}$ Indeed, as observed by Timothy Garton Ash, "British soft power" did play a role at the end of the Cold War. Clearly, this particular power of attraction was not the monopoly of Great Britain, but rather originated in "the Anglo-sphere" or the wider "English speaking world". 46

\section{Conclusions}

The central aim of this article has been to highlight the part played by prominent public intellectuals such as Dahrendorf and Gellner in the dissemination of liberal ideas beyond the Iron Curtain during the crucial years 1985 to 1995. In so doing, they elaborated the concept of an Open Society and participated actively in the formulation of ideas and the launching of projects in Central and Eastern Europe. The focus is therefore upon the power of ideas, as much as the effects that politics and diplomacy create; upon the open society of Europe, rather than the institutions and policies of the European Community.

This article has analysed three fundamental issues concerning the role played by Dahrendorf and Gellner in the years immediately before and after the end of the Cold War. These are the relationship between the acceleration of the process of change in Europe in the second half of the 1980s and the decision by intellectuals to actively engage with it; the part played by the reform movement and increasingly visible change in Central and Eastern Europe in prompting a response from the West among politicians as well as intellectuals; and the centrality of Great Britain as an arena where ideas and projects launched in the name of the Open Society were discussed, elaborated and put to the test.

44. G. SOROS, L'era della fallibilità, Il Sole 24 Ore, Milano, 2007, pp.48-58 (title of the original edition: The Age of Fallibility. Consequences of the War on Terror, United States Public Affairs, New York, 2006).

45. G. SOROS, Soros on Soros: Staying Ahead of the Curve, John Wiley \& Sons, New York, 1995; G. SOROS, Underwriting Democracy: Encouraging Free Enterprise and Democratic Reform Among the Soviets in Eastern Europe, United States Public Affairs, New York, 2004; G. SOROS, Open Society. Reforming Global Capitalism, Little Brown, London, 2000; G. SOROS, The Crash of 2008 and What it Means. The New Paradigm for Financial Markets, Public Affairs, New York, 2008; G. SOROS, The Soros Lectures: At the Central European University, Public Affairs, New York, 2010. See the following Internet sites: http://www.georgesoros.com and http://www.soros.org.

46. See Timothy Garton Ash in conversation with Ilaria Poggiolini, 22nd October 2009, St. Antony's College, Oxford. 
Dahrendorf's ambition to create a "Common Market of the Mind in Europe" which could connect East and West was what inspired the "Oxford Project" and strongly motivated his own active engagement with Central and Eastern Europe. The "marketplace" of ideas that Dahrendorf and others had in mind was a liberal space where ideas could be fielded and exchanged. This particular place could finally be identified with Europe at the end of the Cold War: a place to come back to from the East and a pole of attraction and liberalisation to treasure and strengthen for those already part of it.

British inspired liberalism exercised a "power of cultural attraction" that survived the period immediately following the end of the Cold War and continued beyond to influence the democratic transition in Central and Eastern Europe. This was a kind of "British Soft Power", which while prevalently cultural, was still capable of making a small but significant contribution to the development of Central and Eastern European societies.

The contribution of ideas and activities by the protagonists of the debate surrounding the idea of the Open Society to the process of liberalisation in Central and Eastern Europe in the late 1980s and early 1990s represents a relevant dimension of the European and global political/cultural world at the end of the Cold War. It is also relevant to point out that the return of a free flow of culture between East and West in Europe coincided with the revival of the debate on the future of intra-European relations. The idea of the Open Society played a role not only in conceptual terms but also by inspiring initiatives in favour of all forms of freedom of expression, the rule of law and the revival of civil society in Central and Eastern Europe.

Whether or not what is described above was part of the overall process of British Ostpolitik since the 1980s remains an open question because archival sources are only partially available through the mechanism of FOI requests. However, the personality and intellectual independence of the thinkers discussed in this article seem to suggest at least a two-way street with moments of convergence and divergence. The importance of the "human factor in international politics" is highlighted in the introduction to this issue. A similar argument has been developed in this essay: the "human factor" is represented by the biographies of the protagonists, hence by the course of their very lives. Their origins, the places of their belonging, their life choices, determined not only their single intellectual pathways, but also their public participation in the events that accompanied the end of the Cold War in Europe and the successive period of transition of Central and Eastern Europe towards democracy.

Ralf Dahrendorf reminds us that "in troubled times intellectuals are necessary, but in ordinary times they are just useful". The need for the public participation of such intellectuals in those troubled times is what emerges from this reconstruction of those years together with their enthusiasm and their awareness that they were indeed living in an era of exceptional importance, and gives an additional dimension to the more obviously political and diplomatic dimension of European Community and nationstate policies as the Cold War ended. 


\title{
British Ostpolitik and Polish Westpolitik: 'push and pull' diplomacy
}

\author{
Sara TAVANI
}

\section{Introduction}

Current historiography has, for quite some time, been centred upon the theme of Western Ostpolitik and its influence on Eastern Europe. ${ }^{1}$ More recently, scholarly research has broadened this picture, by linking the Ostpolitik conducted by Western countries to the parallel evolution of their Westpolitik, especially within the EC framework. ${ }^{2}$ Yet, less attention has been paid to the other side of the coin: Eastern policies of opening towards the West. This is of course in part due to the limited availability of archival sources. This article contributes to the wider theme of this issue by investigating the role that Eastern Westpolitik has played in the elaboration of Western Ostpolitik. This shift is based on the central argument that East Europeans were not simply passively affected by Western policies, but purposely pursued cooperation with the West, in spite of Cold War boundaries.

The article focuses, not on the wider West European dimension, but on the main motivations which encouraged those decision-makers who were responsible for British Ostpolitik to respond to the spontaneous emergence of a distinctly national Polish 'Westpolitik'. The aim is to advance an hypothesis of the relevance of British influence on the Polish process of transformation and of British reactions to Polish Westpolitik. It was specifically what we might call a 'push and pull' diplomacy that

1. Historiography dealing with European Ostpolitik's repercussions is rich. Among the most recent J.A. ENGEL (ed.), The Fall of the Berlin Wall: the revolutionary legacy of 1989, Oxford University Press, Oxford, 2009; C.FINK, B. SCAHEFER(eds.), Ostpolitik, 1969-1974: European and global responses, Cambridge University Press, Cambridge, 2009; W. LOTH, G.-H. SOUTOU (eds.), The Making of Détente: Eastern and Western Europe in the Cold War, 1965-75, Routledge, London/New York, 2008; J. von DANNENBERG, The foundations of Ostpolitik. The making of the Moscow Treaty between West Germany and the USSR, Oxford University Press, London and New York, 2008; A. HOFMANN, The emergence of Détente in Europe. Brandt, Kennedy and the formation of Ostpolitik, Routledge, New York, 2007.

2. For instance N.P. LUDLOW (ed.), European integration and the Cold War: Ostpolitik-Westpolitik, 1965-1973, Routledge, London, 2007; and the Conference Britain and Europe in the 1980s: East \& West, University of Pavia, Pavia, 1-2 October 2007, which has been conceptually framed around the idea of a relevant link between British Ostpolitik and Westpolitik. The theme is also discussed by I. POGGIOLINI in this issue and in her essay Thatcher's double track road to the end of the Cold War: the irreconcilability of liberalization and preservation, in: F. BOZO, M.P. REY, P. LUDLOW (eds.), Visions of the end of the Cold War in Europe, Berghahn Books, Oxford, 2010; see also A. DEIGHTON, Ostpolitik or Westpolitik? British Foreign Policy, 1968-75, in: International Affairs, 4(October 1998), pp.893-901; J.F. BROWN, L. GORDON, P. HASSNER, J. JOFFE, Eroding Empire: Western Relations with Eastern Europe, The Brookings Institution, Washington, 1987. 